\title{
Application of Health Welfare Standards in Calemus Dromedarius Breeding in Algeria: Facts and Practical Difficulties
}

\author{
Mammeri Adel* \\ Department of Agronomy, Animals Pathology and Reproduction Control Laboratory, Veterinary Institute, University of Constantine, Algeria
}

Submission: November 11, 2018; Published: November 20, 2018

*Corresponding author: Mammeri Adel, Department of Agronomy, Animals Pathology and Reproduction Control Laboratory, Veterinary Institute, University of Constantine, Algeria

Keywords: Camel welfare; Health status, Camelus dromedaries; constraints; Algeria

\section{Introduction}

Since the beginning of the National Agricultural Development Program, incentive grants have been proposed by the Algerian authorities to revive camel breeding in Algeria [1]. These efforts are supported by the fact that camel breeding is characterized with negligible fodders and stable building costs, in comparison to other ruminants' species. Nevertheless, according to our findings on the field, it turns out that the conduct of camelids' dairy farms, is often characterized by a search for immediate benefits by herders or livestock managers, to the detriment of animals' welfare in production as well as their sanitary status [2]. For example, among the most spread camelids' diseases, subclinical mastitis causes suffering of she-camels, if it is not detected precociously [3]. Also, clostridial diseases as tetanus and enterotoxaemia, mangue caused by Sarcoptes sp., cause pain and death of camels [4]. In addition, the negative influence of stress and unfavorable rearing conditions has been regulated by the recommandations of the Farm Animal Welfare Council [4]. In this mini-review we expose our point of view on the possibility of application of health welfare standards in camel breeding in the situation of Algeria, according to facts and field constraints. Some dominant diseases are done as example.

\section{Clinical and Subclinical Mastitis}

In a study carried out by [5] in Biskra governorate (Algeria), it had been revealed that neither of questioned camel breeders uses sterilizing solution during washing udder. Also, in a recent survey conducted in the same region, results showed that Tetracyclines and Beta-lactamines are the most used antibiotics, during the whole veterinary activity in clinics, particularly to treat urogenital sphere and mammary gland pathologies, followed by Sulfamides and Macrolides. Furthermore, these antimicrobials and antibiotics are used anarchically without sensitivity testing [6]. Mainly, these factors would increase the resistance of some microorganisms to specific antibiotics when occur acute, chronic or subclinical mastitis cases. Additionally, according to [4], holding yards must be designed without protruding objects to minimize injury, in opposite, field observations [5] show that dromedary camels are only enclosed in an iron fence, often at very low height, in beriurban breeding system. Thus, risks of injuries of she-camels' udders would be very high, conducting often to mastitis occurring.

\section{Enterotoxaemia}

Vaccination against clostridial diseases (including tetanus) are recommended if camels are farmed [4]. Some vaccines are efficient against several species of Clostridium including Clostridium tetani, as for example; Coglavax (N.D) made by CEVA (France). According to our field experience, despite such vaccines are often available in Algeria and that veterinarians incite camel herders on their use, as à preventive method, breeders prefer to use them only after the appearance of enterotoxaemia, and often as soon as the losses become heavy. Thus, it turns out that technical support and training of breeders is essential [2]. It is well known that sudden changes in diets must be avoided, particularly the introduction of high protein [4].

\section{Tetanus}

Since specific monovalent vaccines against animal tetanus are practically inexistent on Algerian territory, neither a national vaccination campaign, the epidemic situation would depend more on the vaccination rate with vaccines directed against enterotoxaemia but including Clostridium tetani anatoxins. In fact, breeders are often surprised by the sudden death of their animals following the declaration of tetanus symptoms, so they can't treat them in perfect time, especially with the remoteness of veterinary clinics in regions characterized by abundance of camel herds. Also, 
the rarity of observed tetanus cases by the camel herders return the disease to oblivion.

\section{Mangue}

In severe cases, Sarcoptes sp. proliferation causes thickening of the skin which prevent effective drug penetration for both external and internal treatment. The treatment by the two ways would be continued for three treatments every two weeks, to permit the skin to regain normal texture [4]. Despite the great availability of efficient drugs against parasitic diseases in Algeria, camel herders tend to economize these products, on the one hand by minimizing doses of the active ingredients comparatively to recommended ones, and on the other hand by avoiding repeating the treatment, as it was previously recommended. Moreover, the external use of traditional remedies; such as oils of various kinds, aggravates animals' clinical status, after having captured the soil particles by skin forming thus a thick stratum, that would decrease the skin's absorption capacity for pour-on application drugs.

\section{Conclusion}

Despite worldwide pharmaceutical technologies reached very high levels, the use of drugs and vaccines in the corresponding context and the ideal time, remains at the choice of breeders and under their decision. Often administrative and budgetary obligations guide the decision of the camel herders. Thus, it appears that knowledge of breeding conditions and common diseases in camelids, are not sufficient to prevent losses in herds.
In order to implement the recommendations reported by [4] by camel breeding in Algeria, an increase in the levels of camel herders' awareness of animal welfare and the need to acquire and practice know-how would be essential. In parallel, a state organism should take responsibility for monitoring the application of the recommended standards of animal welfare, taking into consideration the circumstances and constraints of the Algerian camel breeding system.

\section{References}

1. Mammeri A (2016) Periurban circuits of she-camel milk sales in Algeria: the case of wilaya of Biskra (in French). Renc Rech Ruminants, p. 23.

2. Mammeri A (2016) Contribution à l'étude des facteurs de risque des pathologies dominantes en élevage laitier dans les wilayas de Biskra et de Constantine. Thèse de Doctorat d'Etat en Sciences Vétérinaires. Option: Epidémiologie et Santé Animale, Université de Constantine 1: 259.

3. Hadef L, Aggad H, Hamad B, Mahmoud MS, Adaika A (2016) Subclinical mastitis in dairy camels in Algeria: Comparison of screening tests. Acta argiculturae Slovenica, 108(2): 85-92.

4. PISC Report (2006) Model Code of Practice for the welfare of animals: The Camel Camelus dromedaries. ( $2^{\text {nd }}$ edn), PISC Report 86: 25.

5. Mammeri A, Kayoueche FZ, Benmakhlouf A (2014) Periurban breeding practice of One-humped Camel (Camelus dromedarius) in the governorate of Biskra (Algeria). J Ani Prod Adv 4 (5): 403-415.

6. Mammeri A (2018) Antibiotic therapy practices of dairy cows and eventual impact on foodstuffs quality in the Governorate of Biskra, Algeria. Res J Pharm Biol Chem Sci 9(6): 1472-1481.

\begin{tabular}{l} 
Your next submission with Juniper Publishers \\
will reach you the below assets \\
- Quality Editorial service \\
- Swift Peer Review \\
- Reprints availability \\
- E-prints Service \\
- Manuscript Podcast for convenient understanding \\
- Global attainment for your research \\
- Manuscript accessibility in different formats \\
( Pdf, E-pub, Full Text, Audio) \\
- Unceasing customer service \\
Track the below URL for one-step submission \\
https://juniperpublishers.com/online-submission.php \\
\hline
\end{tabular}

